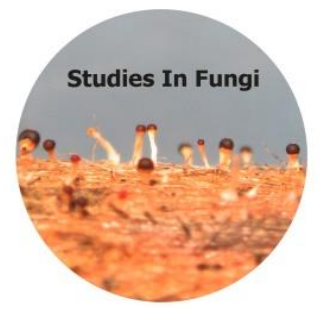

Studies in Fungi 3(1): 264-270 (2018) www.studiesinfungi.org ISSN 2465-4973 Article

Doi 10.5943/sif/3/1/27

Copyright $\odot$ Institute of Animal Science, Chinese Academy of Agricultural Sciences

\title{
First report of lichens from St. Mary's Islands, the south west coast, India
}

\author{
Joseph S, Dudani SN and Nayaka $S^{*}$
}

Lichenology Laboratory, CSIR-National Botanical Research Institute, Rana Pratap Marg, Lucknow, PIN-226 001, Uttar Pradesh, India

Joseph S, Dudani SN, Nayaka S 2018 - First report of lichens from St. Mary's Islands, the south west coast, India. Studies in Fungi 3(1), 264-270, Doi 10.5943/sif/3/1/27

\begin{abstract}
The paper presents the first ever report on lichens of St. Mary's Island with a total of 20 species belonging to 13 genera. Two species, Pertusaria dehiscens var. sekikaica A.W. Archer \& Elix and Porina howeana P.M. McCarthy are reported as new records for India. Rhizocarpon obscuratum (Ach.) A. Massal. is recorded after a gap of 52 years.
\end{abstract}

Key words - Biodiversity - coastal lichens - Karnataka state - lichenized Ascomycota - new records

\section{Introduction}

The St. Mary's Islands are a group of four small islands and several tiny islets located about 6 $\mathrm{km}$ off the Malpe coast in Udupi district of Karnataka. The northernmost island is typically characterized by the presence of columnar joints and is prominently covered by coconut trees due to which it is popularly known as 'Coconut Island'. The other three islands - North Island, Daryabahadurgarh Island and South Island, are located southwards to Coconut Island and together these islands form a north-south archipelago (Fig. 1). The Coconut Island and Northern Island outcrops are considered to be lava flows whereas the Daryabahadurgarh Island is a shallow-level intrusion (Melluso et al. 2009). The geological history indicates that Western India and Eastern Madagascar were contiguous until the middle part of the Late Cretaceous (Katz \& Premoli 1979) but separated due to volcanism occurred in Madagascar (Lacroix 1923, Besairie 1964, Torsvik et al. 2000, Pande et al. 2001). Majestic arrays of multi-faced columns have developed on the Coconut Island owing to the outflow of hot basaltic molten lava dating back to about 60 million years ago. These structures are known as 'columnar joints' which hold considerable geological importance and present a rare view on this island. Owing to these factors, a lot of interest has been generated in these islands during the last few years. However, all the studies that have been carried out on these islands have more or less dealt with geological aspects, and there are no records of any flora including the lichens. Hence, we decided to explore the lichen diversity of Coconut Island (as it is easily accessible and open to the public) for the first time and the results obtained are discussed in this paper.

\section{Materials \& Methods}

The specimens examined in the present study were collected from the rocks, tree twigs and tree barks present on Coconut Island (N13²2'48.8”; E7440'20.3”) on 17 February 2018 by 
authors and were deposited in LWG herbarium. Morphological and anatomical characters were studied by using stereo zoom (Leica S8APO) and light (DM2500) microscopes attached with the camera and the image analysis software. Hand-cut sections were mounted in distilled water and lactophenol cotton blue. The amyloid reactions were tested in Lugol's iodine solution (I) with and without pre-treatment of $\mathrm{KOH}$. All measurements were made on material mounted in distilled water. Chemical analysis was performed on selected species with regular spot tests and thin layer chromatography by following Orange et al. (2001).

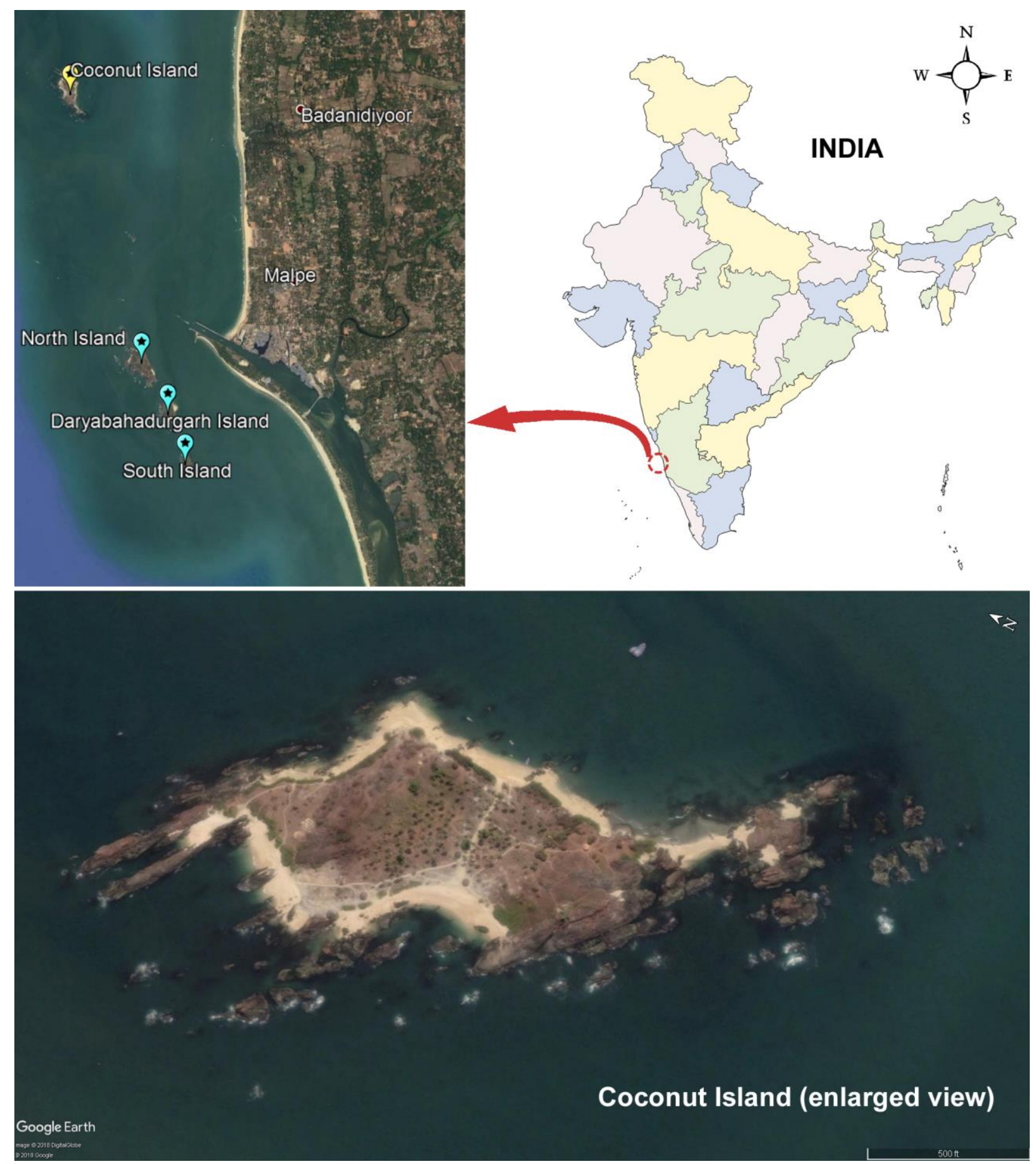

Fig. 1 - Map showing the location of St. Mary’s Islands.

\section{Results \& Discussion}

The present study was resulted 20 lichen species belonging to 13 genera and 11 families in the Coconut Island. Among the lichen families, Lecanoraceae was the most dominant with four 
species followed by Caliciaceae and Pyrenulaceae with three species in each. The lichen genera Lecanora was represented by four species on the island followed by Pyrenula with three species; Dirinaria and Graphis with two species in each. The fruticose lichens were absent on the island whereas the foliose lichens were represented by only three species and the remaining were crustose forms. With respect to the lichen habitats, four species were found growing exclusively saxicolous while two species were growing both as saxicolous and corticolous and the remaining 14 species were exclusively corticolous. Among the host trees, Streblus sp. was found to be harboring maximum lichens (5 spp.) followed by Calophyllum sp. (3 spp.) and Avicennia sp., Cocos sp., Ficus sp., Ziziphus sp. and Pongamia sp. (2 spp. each). Among the notable lichens, an interesting species, Rhizocarpon obscuratum (Ach.) A. Massal. is recorded from India after a gap of 52 years.

\section{Enumeration of the taxa}

Arthonia antillarum (Fée) Nyl. (Arthoniaceae)

The species is characterized by epruinose ascomata with consistently 3 -septate macrocephalic ascospores of 12-20 $\times 2.5-4 \mu \mathrm{m}$. It was found growing on the bark of Ficus sp.

Material examined - 18-032434b (LWG).

Arthothelium abnorme (Ach.) Müll. Arg. (Arthoniaceae)

The species can easily distinguish by its whitish grey thallus, punctate, slightly rounded to lirellate ascomata, pale brownish ascomatal tissues, 8-spored asci, muriform ascospores without larger terminal cell, 15-20 $\times 6-8 \mu \mathrm{m}$, and lacking lichen substances. It was found common and growing on the bark of Avicennia sp.

Materials examined - 18-032421, 18-032427 \& 18-032406 (LWG).

Bacidia medialis (Tuck.) Zahlbr. (Ramalinaceae)

It is a cosmopolitan species characterized by highly variable thallus morphology of cracked to areolate, partly tuberculate to fine granular, sometimes dissolving into granular goniocysts, ascospores baciliform to rod shaped with blunt ends, transversely 3-5-septate, $18-30 \times 2.5-4 \mu \mathrm{m}$. It was common and collected from the barks of Streblus sp. and Avicennia sp.

Materials examined - 18-032414, 18-032417 \& 18-032428 (LWG).

Caloplaca subpoliotera Y. Joshi \& Upreti (Teloschistaceae)

The species can easily distinguish by its saxicolous habitat, rimose-areolate thallus with whitish soredia, orange-red apothecial disc with black margin, small polaribilocular ascospores of $6-9 \times 3-4 \mu \mathrm{m}$.

Materials examined - 18-032419 \& 18-032418 (LWG).

Dirinaria applanata (Fée) D.D. Awasthi (Caliciaceae)

A widely distributed species in the tropical and subtropical regions of the world. It is characterized by sorediate thallus with dichotomous to subdichotomously branched lobes, and the presence of divaricatic acid. The present collection is a sterile specimen found growing on the bark of coconut tree.

Material examined - 18-032416 (LWG).

Dirinaria consimilis (Stirt.) D.D. Awasthi (Caliciaceae)

The species is characterized by sorediate thallus, flabellate to plicate lobes, and the presence of sekikaic acid. It is a commonly distributed species in this island, and the collections are sterile. It was found growing luxuriantly on twigs of Ziziphus sp. as well as on coastal rocks.

Materials examined - 18-032420b, 18-032415a \& 18-032402 (LWG). 
Enterographa pallidella (Nyl.) Redinger (Roccellaceae)

A pantropical species characterized by its pale brownish lirellate ascomata, I+ red hymenial tissue, 8-spored asci, transversely 7-15-septate ascospores of 18-30 $\times 2.5-3.5 \mu \mathrm{m}$, and the presence of gyrophoric acid. It was collected from the bark of Calophyllum sp. and growing along with Graphis species.

Material examined - 18-032424 (LWG).

Graphis cincta (Pers.) Aptroot (Graphidaceae)

The species is characterized by lirellae with thin lateral thalline margin, labia entire, laterally carbonized excipulum, inspersed hymenium, transversely septate ascospores of 35-40 × 6-8 $\mu \mathrm{m}$, and presence of norstictic acid. It was found on the bark of Ziziphus sp. and growing along with Dirinaria consimilis.

Material examined - 18-032420a (LWG).

Graphis subasahinae Nagarkar \& Patw. (Graphidaceae)

A palaeotropical species characterized by slightly branched lirellae, entire labia, laterally carbonized excipulum, non-inspersed hymenium, transversely septate ascospores of 18-28 $\times 5-7$ $\mu \mathrm{m}$, and the presence of norstictic and salazinic acids. It was found growing on the bark of Calophyllum sp.

Materials examined - 18-03424a \& 18-032434a (LWG).

Lecanora achroa Nyl. (Lecanoraceae)

A cosmopolitan species characterized by apothecia with orange brown discs, amphithecium with large crystals, small ascospores of 10-17 $\times 6-9 \mu \mathrm{m}$, and the presence of atranorin and usnic acid. It was collected from the bark of Ficus sp.

Materials examined - 18-032408, 18-032433 \& 18-032426 (LWG).

Lecanora helva Stizenb. (Lecanoraceae)

It is a very common pantropical species can easily distinguishable by its small orange to pale brown apothecial discs, amphithecium with large crystals, small ascospores of 8-14 $\times 4-7 \mu \mathrm{m}$, and the presence of atranorin and methylperlatolic acid. It was collected from the bark of Streblus sp.

Material examined - 18-032401 (LWG).

Lecanora subimmersa (Fée) Vain. (Lecanoraceae)

The species is characterized by saxicolous habitat, rimose-areolate thallus, aspicilioid apothecia, reduced amphithecium with large crystals, ascospores of 8-15 $\times 5-7 \mu \mathrm{m}$, and the presence of atranorin and zeorin.

Material examined - 18-032404 (LWG).

Lecanora tropica Zahlbr. (Lecanoraceae)

It is a common pantropical species characterized by its reddish-brown apothecial discs, amphithecium with large and small crystals, ascospores of 8-17 $\times 6-9 \mu \mathrm{m}$, and the presence of atranorin and zeorin. It was collected from the bark of Streblus sp.

Materials examined - 18-032407 \& 18-032410 (LWG).

Pertusaria dehiscens var. sekikaica A.W. Archer \& Elix (Pertusariaceae)

Fig. 2A

Thallus corticolous, rimose to aerolate, ascomata in fertile verrucae, pertusariate, hemispherical to irregular in shape, ostioles 2-6 per verrucae, asci 4-6-spored, ascospores hyaline, double layered, smooth, 40-56 × 15-22 $\mu \mathrm{m}$.

Chemistry - Thallus $\mathrm{K}+$ yellow, $\mathrm{C}+$ orange-red, $\mathrm{P}-, \mathrm{UV}+$ yellow. lichexanthone, constictic and sekikaic acids detected in TLC.

Material examined - 18-032433 (LWG). 
Notes - The species is morphologically very similar to $P$. dehiscens var. dehiscens Müll. Arg., which lacks sekikaic acid in the thallus. Previously, this variety is known only from the type locality in north-eastern N.S.W, Australia. It is a new record for India and it was found growing on the bark of Streblus sp.

Porina howeana P.M. McCarthy (Porinaceae)

Fig. 2B

Thallus saxicolous, dark brown to olivaceous brown, perithecia semi-immersed to superficial, blackish, base studded with white crystals, ostiole inconspicuous, involucrellum blackish in surface view, orange brown in section, excipulum hyaline to pale yellow, asci 8-spored, ascospores hyaline, 5-7-septate, 24-30 $\times 4.5-5.5 \mu \mathrm{m}$. Pycnidia numerous, semi-immersed to superficial, dark brown to blackish above, conidia bacilliform, 2.5-4.5 × 1-2 $\mu \mathrm{m}$.

Chemistry - Thallus K-, C-, P-, UV-. no chemicals detected in TLC.

Material examined - 18-032415b (LWG).

Notes - The species is close to P. adflata Müll. Arg. and P. fluminea P.M. McCarthy \& P.N. Johnson but both the species differ in having consistently 5 -septate ascospores. In India, $P$. subinterestes ( $\mathrm{Nyl}$.) Müll. Arg is the only known saxicolous species that differ from $P$. howeana by its yellowish to greenish glossy thallus, consistently 7-septate ascospores of 24-34 $\times 5-9 \mu \mathrm{m}$. Previously, the species is known from Lord Howe Island, Australia, and it's a new record for India.
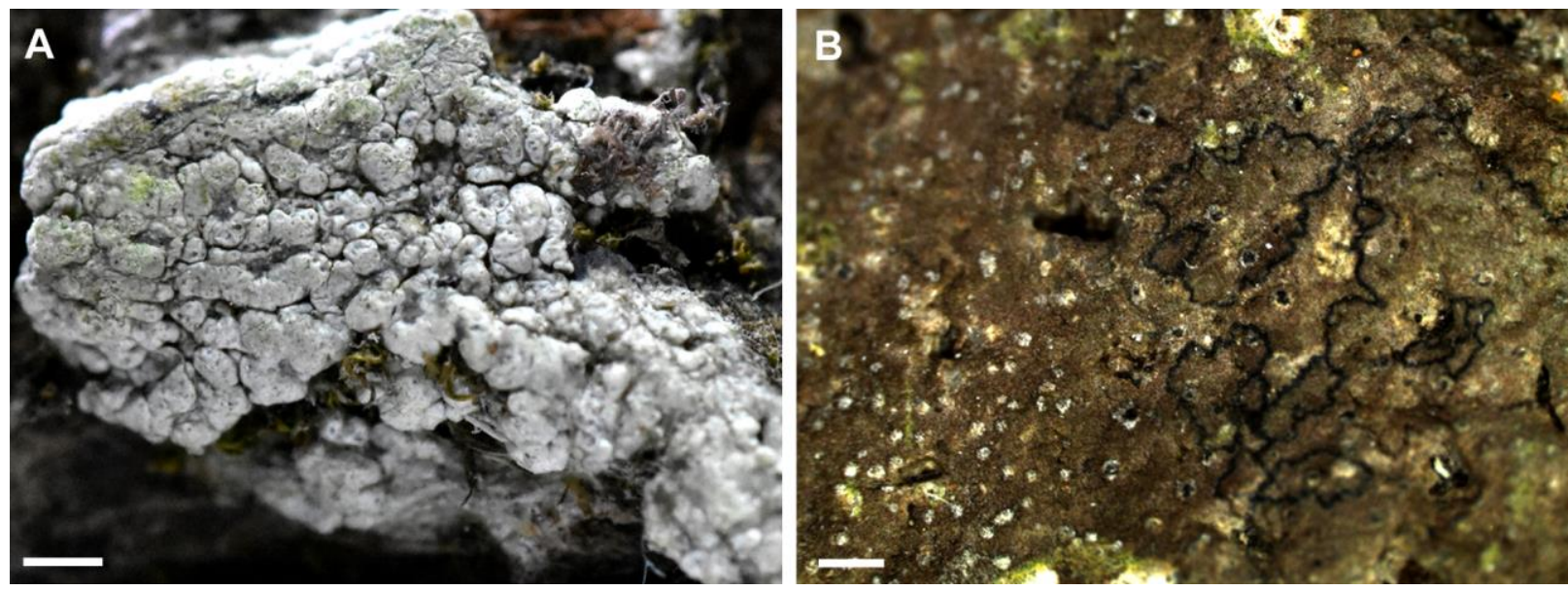

Fig. 2 - Habits. A Pertusaria dehiscens var. sekikaica A.W. Archer \& Elix. B Porina howeana P.M. McCarthy. Scale bars: A, B = $1 \mathrm{~mm}$.

Pyrenula minor Fée (Pyrenulaceae)

The species is characterized by UV- thallus, solitary blackish perithecia, rarely aggregated, apical ostiole, hamathecium not inspersed, 3 -septate ascospores of $14-19 \times 6-7 \mu \mathrm{m}$. It was found common in the barks of Pongamia sp.

Materials examined - 18-032411, 18-032412, 18-032435 \& 18-032430 (LWG).

Pyrenula sublaevigata (Patw. \& Makhija) Upreti (Pyrenulaceae)

The species is characterized by pseudocyphellate pale yellowish thallus, solitary black perithecia with basal thalline cover, apical ostioles, hamathecium inspersed, muriform ascospores of 38-42 $\times 17-22 \mu \mathrm{m}$. It was collected from the barks of Streblus and Calophyllum sp.

Materials examined - 18-032425, 18-032429, 18-032413 \& 18-032431 (LWG).

Pyrenula thelomorpha Tuck. (Pyrenulaceae)

It is a pantropical species characterized by black solitary perithecia, rarely aggregated, ostioles apical, hamathecium not inspersed, muriform ascospores of 34-37 $\times 11-14 \mu \mathrm{m}$. It was collected from the bark of Pongamia sp.

Material examined - 18-032409 (LWG). 
Pyxine cocoes (Sw.) Nyl. (Caliciaceae)

It is a cosmopolitan species can easily distinguish by its UV+ yellow thallus, laminal and marginal soredia, and $\mathrm{K}$ - white medulla, and the presence of lichexanthone. It was found common in this island and growing on the bark of coconut trees and the coastal rocks. All the collections from the island are sterile.

Materials examined - 18-032422 \& 18-032403 (LWG).

\section{Rhizocarpon obscuratum (Ach.) A. Massal. (Rhizocarpaceae)}

The species is characterized by thallus UV-, brown grey to dark grey, rimose-areolate, immersed apothecia, asci 6-8-spored, and brown submuriform ascospores of 25-33 $\times 10-14 \mu \mathrm{m}$. It was found growing over the coastal rocks.

Material examined - 18-032405 (LWG).

Notes - The species is reported from India by Schubert \& Klement (1966) based on the collections from Maharashtra in the year 1962 by H. Meusel and R. Schubert. However, the species was not mentioned in the revision of Rhizocarpon in India by Awasthi \& Singh (1977) and it may be overlooked by the authors. Singh (1980) included the species in his book "Lichenology in Indian Subcontinent 1966-1977". Later on, Awasthi (1991) keyed out this species in "A key to microlichens of India, Nepal and Sri Lanka". Later, Singh \& Sinha (2010) also not mentioned about this species in Indian lichens checklist. In the book "Lichens of Maharashtra" by Makhija et al. (2014), included this species based on the earlier report but the authors were also mentioned their inability to recollect from the locality. So, it is an interesting record reporting from India after a gap of 52 years.

\section{Acknowledgements}

The authors wish to thank the Director of CSIR-NBRI for providing the laboratory and herbarium facilities, and to Dr. D.K. Upreti for his encouragement and help with the identification of Pyrenula and Porina specimens. Two of the authors (SJ \& SND) wish to thank SERB for providing financial assistance under the NPDF scheme (PDF/2016/002054 \& PDF/2016/001897).

\section{References}

Awasthi DD. 1991 - A Key to the microlichens of India, Nepal and Sri Lanka. Bibliotheca Lichenologica 40, 1-337.

Awasthi DD, Singh SR. 1977 - The lichen genus Rhizocarpon (Ram.) Th. Fr. In India. Kavaka 5, 49-58.

Besairie H. 1964 - Geological map of Madagascar, 1:1000000 scale. Service Geologique de Madagascar, Tananarive.

Katz MB, Premoli C. 1979 - India and Madagascar in Gondwanaland based on matching Precambrian lineaments. Nature 279, 312-315.

Lacroix A. 1923 - Mineralogie du Madagascar, Vol. 3. Augustin Challamel, Paris.

Makhija U, Chitale G, Dube A. 2014 - Lichens of Maharashtra. Bishen Singh Mahendra Pal Singh, Dehra Dun, India.

Melluso L, Sheth HC, Mahoney JJ, Morra V et al. 2009 - Correlations between silicic volcanic rocks of the St Mary's Islands (southwestern India) and eastern Madagascar: implications for Late Cretaceous India-Madagascar reconstructions. Journal of the Geological Society 166, 283-294.

Orange A, James PW, White FJ. 2001 - Microchemical Methods for the Identification of Lichens. British Lichen Society, London.

Pande K, Sheth HC, Bhutani R. 2001 - 40Ar-39Ar age of the St. Mary islands volcanics, southern India: record of India-Madagascar break-up on the Indian subcontinent. Earth and Planetary Science Letters 193, 39-46. 
Schubert R, Klement O. 1966 - Beitrag zur Flechten-Flora von Nord-und Mittelindien. Nova Hedwigia 11, 1-73.

Singh A. 1980 - Lichenology in Indian Subcontinent 1966-1977. Economic Botany Information Centre, National Botanical Research Institute, Lucknow, India.

Singh KP, Sinha GP. 2010 - Indian Lichens: An Annotated Checklist. Botanical Survey of India, Kolkata, India.

Torsvik TH, Tucker RD, Ashwal LD, Carter LM et al. 2000 - Late Cretaceous India- Madagascar fit and timing of break-up related magmatism. Terra Nova 12, 220-224. 